\title{
The Eurasian Way of War. Military Practice in Seventh-Century China and Byzantium. Asian States and Empires. By David A. Graff. London-New York: Routledge, 2016. 208 pp.
}

\section{Gergely Csiky}

Institute of Archaeology, Research Centre for the Humanities, ELKH, H-1097 Budapest, Tóth Kálmán u. 4, Hungary; csiky.gergely@abtk.hu

The name David Andrew Graff is familiar to those interested in premodern Asian military history. The sinologist author has studied warfare in medieval China throughout his academic career and since 1998 has been the editor of the Journal of Chinese Military History and secretary of the Chinese Military History Society. In 2002, he published a fundamental monograph on medieval Chinese warfare in the series Warfare and History published by Routledge. ${ }^{1}$ A professor at Kansas State University, he is an acknowledged authority on Chinese military history.

The significance of the monograph reviewed here, The Eurasian Way of War. Military Practice in Seventh-Century China and Byzantium, extends beyond East Asian or Chinese military history. It attempts to answer questions of technology transfer and warfare, such as the spread of military innovations, and questions the validity of regional ways of war by comparing seventh-century Byzantine and Tang warfare.

The book raises a bold question in comparing late antique military manuals from empires located at the opposite edges of the Old World. The two key texts are the Strategikon, written at the turn of the seventh century and attributed to the emperor Maurice, and a lost Chinese military manual (Li Jing bingfa) by a seventh-century Tang general, Li Jing, which has survived only in extracts. Graff did even more: he exhaustively described seventh-century Chinese and Byzantine warfare and attempted to explain the convergence of these two independent systems.

Consequently, the book is of interest not only to military historians but also to researchers interested in global connectivity, interactions between the steppe and the sown, and the history of technology. The positive reception of this monograph

1 Graff, Medieval Chinese Warfare. 
by scholars in the fields of Mongolian studies, ${ }^{2}$ Chinese-Türk cultural relations, ${ }^{3}$ late antique histor $y^{4}$ and military history $y^{5}$ illustrates its popularity in various disciplines.

The structure of the monograph is logical and practical, consisting of seven chapters: the first historiographical chapter on the relationship between war and culture is followed by a presentation of the seventh-century Chinese (Sui and early Tang) and Byzantine armies, highlighting their resources, weaponry, and tactics (chapters 2 and 4). The second half of the book offers interpretative answers to the above questions, emphasizing the role of literary and textual traditions in the record and transfer of military knowledge. The investigative chapters (6 and 7) present the sporadic diplomatic contacts and interactions of these remote superpowers as well as the intermediary role of the nomadic confederacies and empires that lay between them. Finally, the author explains the comparable features and convergences of these two separate military systems, which had similar adaptive answers to nomadic threats.

The historiographical essay on the relationship between war and culture explores the question of how the contents of a seventh-century Chinese and a European military manual could be so similar despite the vast geographical distance. Since the mid-twentieth century, a belief in general principles of war was replaced by a cultural-historical approach that studied various ways of war and strategic cultures. The most prominent military historian of our day, John Keegan, even described war as an "expression of culture." The notion of a Western way of war as a particular and timeless European type of warfare deriving from the tactics of ancient Greeks hoplites and characterized by quick problem solving, decisive battle, and frontal attacks ${ }^{7}$ stems from this culture-centric approach. Its counterpart, the Oriental way of war was characterized by "evasion, delay and indirectness" by Keegan. ${ }^{8}$ The information obtained from the two main sources presented by this book contradict this static framework. During the seventh century, Chinese warfare was too western and aggressive, while the Byzantine way of war proved to be too Asian and defensive, which questions the exactness of these categories. In his book, Graff cut the Gordian knot and introduced the term Eurasian way of war.

The two empires, the Sui/Tang China and the Eastern Roman Empire, possessed similar resources, and their territories and populations were comparable; the main difference between them was their geographic layout. China was basically a continental

\footnotetext{
2 May, "Review of The Eurasian Way of War."

3 Skaff, "Review of The Eurasian Way of War."

4 Decker, "Review of The Eurasian Way of War."

5 Davies, "Review of The Eurasian Way of War."

6 Keegan, History of Warfare, 12.

7 Hanson, Western Way of War; Hanson, Carnage and Culture.

8 Keegan, History of Warfare, 387-88.
} 
power with limited use of the navy, while the Eastern Roman Empire surrounded the Mediterranean Sea, which resulted in its having a powerful fleet that was able to exploit its long and articulated coastline. The geostrategic considerations addressed in the book are difficult to grasp, however, because of the lack of maps. The two empires also differed in the number and organization of soldiers: China introduced the system of part-time military service (fubing) in the Warring States period, while the Byzantine Empire formed a permanent and professional army smaller in number. At the same time, the expeditionary troops numbered between 12,000 and 20,000 in both areas.

The armies of these two states used weaponry on a similar technological level; the only significant exception was the frequent Chinese use of handheld crossbows. At the same time, at the end of the sixth century, several types of military equipment appeared in the East Roman army as well as in early Avar burials. These artefacts-lamellar armor, ${ }^{9}$ traction trebuchets, and single-edged ring-pommel swords ${ }^{10}$ (wrongly described as sabers in the book)-were formerly unknown in western Eurasia while frequently used in ancient China. The two military manuals report on similar tactical elements, and risk calculations played a comparable role in the military decisions of both states.

Campaigns relied on fundamental logistical planning like transfer, accommodation, and food supply. The author's comparison of Chinese and Byzantine logistics, however, fails in the absence of recent and relevant literature on the logistical support of the East Roman Empire. ${ }^{11}$ He ascribes the poor logistics of the Byzantine Empire to the damaged roads and lack of distribution centers for supplies, which contrasted with the canals that interlaced Tang China. In fact, a dense network of fortresses and fortified cities with granaries served the logistical needs of the East Roman army between the fourth and seventh centuries. Fortifications were not only designed for passive defense but also for an active distribution of the food supply. ${ }^{12}$ The Danube as the main artery of riverine transport compensated for the lack of canals in the frontier zone. ${ }^{13}$ The author rightly argues that fortresses and sieges played a significant role; however, some minor inaccuracies occur in his descriptions of major sieges. ${ }^{14}$

9 Bugarski, "Contribution"; Glad, "Empire's Influence on Barbarian Elites”; Glad, L'armement, 113-27.

10 Csiky, Avar-Age Polearms, 233-34; in the Byzantine context: Justiniana Prima (Caričin Grad, a church's crypt): Quast, "Einige alte und neue Waffenfunde," 361; Glad, L'armement, 319, 324.

11 Haldon, General Issues; Whately, "Organisation”; Sarantis, "Military Provisionining."

12 Sarantis, "Waging War in Late Antiquity," 36-40.

13 On the Danube fleet and transport: Bounegru and Zahariade, Les forces navales; Karagiorgou, "LR2"; Curta, "Amphorae and Seals."

14 The author attributes the Avar siege of Constantinople in the summer of 626 also to the Persians 
The seventh-century Chinese and Byzantine military practice matched even modern expectations in terms of organization, discipline, and risk management. This consciousness derived from the accumulation of several generations of experience passed on in the literary and textual traditions that characterized both bureaucratic empires. Both states had a great tradition of writing military manuals that were used and even brought to campaigns by generals. The administrations of both armies kept a large number of records, lists, and reports. These documents survived only as paper fragments from the Western Regions of Tang China or in the form of late antique papyruses from Egypt. These living traditions inherited from Antiquity led to the continuous development of armies and generalship.

The vast distance between China and the Mediterranean calls into serious question all historical comparisons between these remote areas; however, the two empires were aware of each other and had diplomatic and commercial relations beginning in the Han-period. These accidental and sparse encounters and the blurred and uncertain information they had on each other limited the spread of military innovations.

Both empires had close contacts with their northern nomadic neighbors (the Türks and Avars), who provided a link via the Eurasian steppe zone between the East and West. After reviewing sources and literature on the origin of the Avar elite and enumerating, based on the Strategikon, a series of East Asian military innovations adopted by the Byzantines, the author concludes the Avars, ${ }^{15}$ migrating from Inner Asia, acted as a transmission vector of East Asian technology.

The description of Avar-Byzantine interactions contains several inaccuracies. The development of the saber cannot be dated to the period of Avar migration (mid-sixth century); it was a process that occurred approximately hundred years later. ${ }^{16}$ Moreover, the paramerion, interpreted as a single-edged sword or saber, was a weapon of the Middle Byzantine period (ninth-tenth centuries). ${ }^{17}$ The Chinese origin of P-shaped suspension loops is highly questionable since they appear contemporary with the European specimens at the end of the sixth century in China. ${ }^{18}$ Ring-pommel swords represent a new element in the list of weapons of Asian origin: such swords were frequent in the burials of the early Avar elite from the DanubeTisza Interfluve (Central Hungary) and had no local precedents. At the same time,

located on the Asian side of the Bosporus, although they could not have participated in the siege: Hurbanič, Avar Siege of Constantinople in 626, 205-7.

15 New palaeogenetic data on the origin of the Avar elite: Csáky, "Genetic Insights."

16 Csiky, Avar-Age Polearms, 192-214, 318-25.

17 Haldon, "Some Aspects of Byzantine Military Technology," 31; Theotokis, "Military Technology," 448-49.

18 The earliest P-shaped suspension loop from China is dated to 569: Koch, "Überlegungen," 574; Csiky, Avar-Age Polearms, 311-14. 
this weapon type had been popular in China since the fourth century, and new Inner Asian finds confirm the possibility of Avar transmission. ${ }^{19}$

Lamellar armor and stirrups were in use in China long before their arrival in Europe around the formation of the Avar Qaghanate in the Danube Basin. ${ }^{20}$ Like other researchers, Graff regards the European appearance of the traction trebuchet a result of Avar transmission. The exact date of the adoption of stirrups and traction trebuchets by the Byzantines is not as clear. Stirrups, while first mentioned in Maurice's Strategikon, are not listed there among the innovations of Avar origin; the work does not even emphasize their novelty. Moreover, archaeological evidence from the Balkans indicates that stirrups were in wide use among the Byzantines at the end of the sixth century, although their shape and manufacturing technique distinguished them from stirrups found in Avar burials. ${ }^{21}$ According to some philological analyses of the Strategikon, Byzantines used stirrups in the first half of the sixth century. ${ }^{22}$

Traction trebuchets replaced early Roman torsion artillery, especially the onager, offering a simpler technique, larger projectiles, and a greater range. The early sixth-century sources refer to this siege engine as a helepolis, which was used by the Byzantine army even before the arrival of the Avars to Europe..$^{23}$ Theophylact's anecdote about Bouzas, a Byzantine traitor at the siege of Appiaria who allegedly taught the Avars how to build siege engines, reveals further contradictions. Besides the literary topoi included in the story, it points to the fact that not only the Avars used such siege engines earlier, but also the Eastern European Kutrigurs preceding them. ${ }^{24}$ Traction trebuchets were already known in the Arabian Peninsula in the early seventh century, ${ }^{25}$ which questions the hypothesis that transmission occurred through the steppe and suggests the transfer of Near Eastern technology was via the Sasanians.

Graff regards the Avar transmission of the mentioned weapons and military equipment as proved. However, he refuses to consider the possibility of a nomadic mediation of tactical elements and ideas because of the lack of literacy among the Avars. Furthermore, the direction, date, and way of transmission of these weapons and military equipment are also uncertain.

19 Csiky, Avar-Age Polearms, 233-34, 315-18.

20 On Chinese lamellar armor: Dien, "Study of Early Chinese Armor"; Csiky, "Transformation of Horse Riding."

21 Bugarski, "Ostava iz Streževa”; Ivanišević and Bugarski, "Les étriers byzantins.”

22 Kraft, "Lat.-griech. scala"; Šuvalov, "Dva železnych stremeni."

23 Petersen, Siege Warfare, 411.

24 Kardaras, "Episode of Bousas (586/7)."

25 Chevedden, "Artillery of King James I"; Chevedden, "Hybrid Trebuchet"; Petersen, Siege Warfare, 406-29. 
In the final chapter of his book, David A. Graff formulates a comprehensive thesis according to which not only was the military equipment of the armies in Sui/Tang China and the Byzantine Empire in the sixth-seventh centuries similar, but so too were their tactics, the logistics of their campaigns, and even their longterm strategic targets. Graff ascribed these common points to the similar challenges these empires faced. Throughout their history, both empires confronted the troops of nomadic confederacies of the Eurasian steppe, which determined their weaponry, tactics, and strategic thought, which were partly conveyed in their literary traditions and partly used by the nomadic federates (or mercenaries) serving in their armies.

Nomadic art of war fundamentally influenced Byzantine and Chinese warfare and transformed the armies of both empires. However, these two states experienced these impacts in different ways, and not only nomads impacted their military affairs. The biggest difference between China and Byzantium resulted from the three-hundred-year-long fragmentation before Li Jing, a period that was characterized by nonHan, nomadic rule in northern China. Barbarian rule was manifest not only in the imperial family and the power of a small elite but in the appearance of several nomad groups that had immigrated to the empire and acculturated to the Chinese civilization while still preserving their language, customs, and way of war. ${ }^{26}$ The position of this barbarian elite is comparable to the Germanic kingdoms on the ruins of the West Roman Empire. These rulers accepted their dependence on the (East or West) Roman emperor, ${ }^{27}$ while northern barbarians in China founded imperial dynasties. In contrast, the East Roman Empire maintained its Roman imperial power, legal system, and culture, as well as its Greek language and Christian religion. In this empire, the army employed nomadic cavalry only as federates and experienced significant Germanic influence on its military affairs.

Ignoring the fundamental political, social, and cultural differences between the two empires, the author emphasizes religion and human resources as distinguishing factors. The Christian Byzantine Empire provided strong ideological support for its armed forces, while China's enormous human resources-enabling massive invasions of Korea or the Türk Qaghanate-compensated for its religious fragmentation. Following Luttwak, ${ }^{28}$ Graff characterizes the Byzantine "grand strategy" as one of diplomacy, bribery, and alliance-building, which was only valid for some periods and regions. The Byzantine Empire's responses to various threat ${ }^{29}$ was shaped by the

26 Dien, Six Dynasties Civilization; Lewis, China between Empires, 54-85; Holcombe, "Xianbei in Chinese History"; Dien and Knapp, Cambridge History of China 2.

27 Scholl, "Imitatio Imperii?."

28 Luttwak, Grand Strategy.

29 Sarantis, "Waging War in Late Antiquity." 
ever-changing combinations of imperial ambitions and regional strategies instead of an overarching vision or grand strategy.

\section{Bibliography}

Bounegru, Octavian and Mihail Zahariade. Les forces navales du Bas Danube et de la mer Noire aux Ier-VIe siècles. Colloquia Pontica 2. Oxford: Oxbow, 1996.

Bugarski, Ivan. "A Contribution to the Study of Lamellar Armours." Starinar 55 (2005): 161-78. https://doi.org/10.2298/STA0555161B.

Bugarski, Ivan. "Ostava iz Streževa: uzengije u ranovizantijskom kontekstu" [The Streževo Hoard: Stirrups in the Early Byzantine Context]. In Niš $i$ Vizantija V. [Niš and the Byzantine Empire], 251-67. Niš: Niški Kulturni Centar, 2007.

Chevedden, Paul E. "The Artillery of King James I the Conqueror." In Iberia and the Mediterranean World of the Middle Ages: Essays in Honor of Robert I. Burns, S.J., edited by Paul E. Chevedden, Donald J. Kagay, and Paul G. Padilla, 47-93. Leiden: Brill, 1996.

Chevedden, Paul E. “The Hybrid Trebuchet: The Halfway Step to the Counterweight Trebuchet." In On the Social Origins of Medieval Institutions: Essays in Honor of Joseph F. O'Callaghan, edited by Donald J. Kagay and Theresa M. Vann, 179-222. Leiden: Brill, 1998.

Curta, Florin. "Amphorae and Seals: the 'Sub-Byzantine' Avars and the Quaestura Exercitus." In Between Byzantium and the Steppe: Archaeological and Historical Studies in Honour of Csanád Bálint on the Occasion of His $70^{\text {th }}$ Birthday, edited by Ádám Bollók, Gergely Csiky, and Tivadar Vida, 307-34. Budapest: Institute of Archaeology, Research Centre for the Humanities, Hungarian Academy of Sciences, 2016.

Csáky, Veronika, Dániel Gerber, István Koncz, Gergely Csiky, Balázs G. Mende, Bea Szeifert, Balázs Egyed, Horolma Pamjav, Antónia Marcsik, Erika Molnár, György Pálfi, András Gulyás, Bernadett Kovacsóczy, Gabriella M. Lezsák, Gábor Lőrinczy, Anna Szécsényi-Nagy, and Tivadar Vida. "Genetic Insights into the Social Organisation of the Avar Period Elite in the $7^{\text {th }}$ Century AD Carpathian Basin.” Nature: Scientific Reports 10, no. 1 (2020): 948. https://doi. org/10.1038/s41598-019-57378-8.

Csiky, Gergely. Avar-Age Polearms and Edged Weapons: Classification, Typology, Chronology and Technology. Leiden-Boston: Brill, 2015. https://doi. org/10.1163/9789004304543.

Csiky, Gergely. "The Transformation of Horse Riding in the Steppes during the 1st Millenium AD: Considerations on the Spread of Stirrups in Eurasia." In From the Huns to the Turks - Mounted Warriors in Europe and Central Asia, edited 
by Falko Daim, Harald Meller, and Walter Pohl. Halle: Landesmuseum für Vorgeschichte Halle, forthcoming.

Davies, Gwynn. "Review of The Eurasian Way of War: Military Practice in Seventh-

Century China and Byzantium, by David A. Graff." Journal of Military History 81, no. 2 (2017): 542-44.

Decker, Michael J. "Review of The Eurasian Way of War: Military Practice in Seventh-

Century China and Byzantium, by David A. Graff." The American Historical Review 122, no. 3 (2017): 802-3. https://doi.org/10.1093/ahr/122.3.802.

Dien, Albert E. Six Dynasties Civilization. New Haven-London-Beijing: Yale University Press, 2007.

Dien, Albert E. "A Study of Early Chinese Armor." Artibus Asiae 43, no. 2 (1981): 5-66. https://doi.org/10.2307/3249826.

Dien, Albert E. and Keith N. Knapp. The Cambridge History of China 2: The Six Dynasties, 220-589. Cambridge: Cambridge University Press, 2019. https://doi. org/10.1017/9781139107334.

Glad, Damien. L'armement dans la région balkanique à l'époque romaine tardive et protobyzantine (284-641). Héritage, adaptation et innovation. Bibliothèque de l'Antiquité tardive 30. Turnhout: Brepols, 2015.

Glad, Damien. "The Empire's Influence on Barbarian Elites from the Pontus to the Rhine ( $5^{\text {th }}-7^{\text {th }}$ Centuries): A Case Study of Lamellar Weapons and Segmental Helmet." In The Pontic-Danubian Realm in the Period of the Great Migration, edited by Vujadin Ivanišević and Ivan Bugarski, 349-62. Paris-Belgrade: College de France-CNRS, 2012.

Graff, David A. Medieval Chinese Warfare 300-900: Warfare and History. LondonNew York: Routledge, 2002.

Haldon, John. "Some Aspects of Byzantine Military Technology from the Sixth to the Tenth Centuries." Byzantine and Modern Greek Studies 1, no. 1 (1975): 11-47. https://doi.org/10.1179/030701375790158220.

Haldon, John, ed. General Issues in the Study of Medieval Logistics: Sources, Problems and Methodologies. Leiden-Boston: Brill, 2006.

Hanson, Victor Davies. Carnage and Culture: Landmark Battles in the Rise of Western Power. New York: Anchor, 2001.

Hanson, Victor Davies. The Western Way of War: Infantry Battle in Classical Greece. New York: University of California Press, 1989.

Holcombe, Charles. “The Xianbei in Chinese History.” Early Medieval China 2013, no. 19 (2013): 1-38. https://doi.org/10.1179/1529910413Z.0000000006.

Hurbanič, Martin. The Avar Siege of Constantinople in 626: History and Legend. London:PalgraveMacmillan,2019.https://doi.org/10.1007/978-3-030-16684-7. 
Ivanišević, Vujadin and Ivan Bugarski. "Les étriers byzantins: la documentation du

Balkan central." In Le cheval dans les sociétés antiques et médiévales: Actes des Journées d'étude internationales organisées par l'UMR 7044. (Étude des civilisations de l'Antiquité), Strasbourg, 6-7 novembre 2009, edited by Stavros Lazaris, 135-42. Turnhout: Brepols, 2012. https://doi.org/10.1484/M.BAT-EB.5.100769.

Karagiorgou, Olga. "LR2: a Container for the Military 'Annona' on the Danubian Border?" In Economy and Exchange in the Eastern Mediterranean during Late Antiquity, edited by Sean A. Kingsley and Michael Decker, 129-66. Oxford: Oxbow, 2001.

Kardaras, Georgios. "The Episode of Bousas (586/7) and the Use of Siege Engines by the Avars." Byzantinoslavica 63, no. 1 (2005): 53-65.

Keegan, John. A History of Warfare. New York: Vintage Books, 1994.

Koch, Alexander. "Überlegungen zum Transfer von Schwerttrag- und Kampfesweise im frühen Mittelalter am Beispiel chinesischer Schwerter mit P-formigen Tragriemenhaltern aus dem 6.-8. Jahrhundert n. Chr." Jahrbuch des Römisch-Germanischen Zentralmuseums 45, no. 2 (1998): 571-98. https://doi. org/10.11588/jrgzm.1998.2.44160.

Kraft, Ulrich. "Lat.-griech. scala als spätantike Bezeichnung für den Steigbügel, und die Benennungen des Steigbügels bei anderen Völkern." In Le cheval dans les sociétés antiques et médiévales: Actes des Journées d'étude internationales organisées par l'UMR 7044 (Étude des civilisations de l'Antiquité) Strasbourg, 6-7 novembre 2009, edited by Stavros Lazaris, 155-92. Turnhout: Brepols, 2012. https://doi.org/10.1484/M.BAT-EB.5.100771.

Lewis, Mark Edward. China between Empires: The Northern and Southern Dynasities. Cambridge-London: Harvard University Press, 2009. https://doi. org/10.2307/j.ctv1kmj7vz.

Luttwak, Edward N. The Grand Strategy of the Byzantine Empire. CambridgeLondon: Harvard University Press, 2009. https://doi.org/10.2307/j.ctvjhzrf5.

May, Timothy. "Review of The Eurasian Way of War: Military Practice in SeventhCentury China and Byzantium, by David A. Graff." Mongolian Studies 37 (2015): 104-6.

Petersen, Leif Inge Ree. Siege Warfare and Military Organization in the Successor States (400-800 AD): Byzantium, the West and Islam. History of Warfare 91. Leiden-Boston: Brill, 2013. https://doi.org/10.1163/978900425446.

Quast, Dieter. "Einige alte und neue Waffenfunde aus dem frühbyzantinischen Reich." In Thesaurus Avarorum: Régészeti tanulmányok Garam Éva tiszteletére - Archaeological Studies in Honour of Éva Garam, edited by Tivadar Vida, 351-70. Budapest: ELTE BTK Régészettudományi Intézet-Magyar Nemzeti Múzeum, 2012. 
Sarantis, Alexander. "Military Provisionining in the Sixth-Century Balkans." Journal of Late Antiquity 12, no. 2 (2019): 329-79. https://doi.org/10.1353/jla.2019.0019. Sarantis, Alexander. "Waging War in Late Antiquity." In War and Warfare in Late Antiquity 8.1, 1-98. Leiden-Boston: Brill, 2013. https://doi. org/10.1163/9789004252585_002.

Scholl, Christian. "Imitatio Imperii? Elements of Imperial Rule in the Barbarian Successor States of the Roman West." In Transcultural Approaches to the Concept of Imperial Rule in the Middle Ages, edited by Christian Scholl, Torben R. Gebhardt, and Jan Clauß, 19-38. Vienna: Peter Lang, 2017. https:// doi.org/10.3726/978-3-653-05232-9.

Skaff, Jonathan Karam. "Review of The Eurasian Way of War: Military Practice in Seventh-Century China and Byzantium, written by David A. Graff." Journal of Chinese Military History 6, no. 2 (2017): 226-28. https://doi. org/10.1163/22127453-12341320.

Šuvalov, P. V. "Dva železnych stremeni" [Two Iron Stirrups]. In KOINON DORON: Issledovanija i esse $v$ čest 60-letnego jubileja Valerija Pavloviča Nikonorova ot druzej i kolleg [Studies and Essays in Honour of Valerii P. Nikonorovon the Occasion of His Sixtieth Birthday Presented by Friends and Colleagues], edited by Alexander A. Sinitsyn and Maxim M. Kholod, 568-76. St. Petersburg: St. Petersburg State University, Faculty of Philology 2014.

Theotokis, Georgios. "Military Technology: Production and Use of Weapons." In A Companion to the Byzantine Culture of War, ca. 300-1204, edited by Yannis Stouraites, 440-72. Leiden-Boston: Brill, 2018. https://doi. org/10.1163/9789004363731_014.

Whately, Conor. "Organisation and Life in the Late Roman Military: A Bibliographic Essay." In War and Warfare in Late Antiquity. Late Antique Archaeology 8.1, edited by Alexander Sarantis and Neil Christie, 209-38. Leiden-Boston: Brill, 2013. https://doi.org/10.1163/9789004252585_006. 